\title{
Hyperreal Identity in William Gibson's Neuromancer
}

\author{
Dea Anugrah Santoso \\ Universitas Negeri Surabaya \\ Surabaya, Indonesia \\ deasantoso@mhs.unesa.ac.id
}

\author{
Mamik Tri Wedawati \\ Universitas Negeri Surabaya \\ Surabaya, Indonesia \\ mamikunesa@gmail.com
}

\begin{abstract}
This study focuses on the case of hyperreal identity issue about what is real and not according to the character's identity that appeared and depicted in the main character, Case, perceive reality and thus he become confused in distinguish between realities and also beliefs of his own identity which affect by technology. The data source of this study was the novel by William Ford Gibson entitled Neuromancer. The main data is taken from data resources which implies the hyperreal identity and it impacts to the main character, Case. The main data were analysed together with supporting data taken from books, literary criticism, articles and related articles. The study uses hyperreality theory formulated by French sociologist, Jean Baudrillard, to find out the identity problems in the play that related to the hyperreal identity. This study proposes two statement of the problems: (1) How is hyperreal identity of Case being depicted in Neuromancer by Wiliam Gibson? (2) How does the finding identity process of the main character, Case, develop his hyperreal identity? The results of this study indicate that Case's identity is a form of hyperreal identity. The character presented in this novel use technology as drugs that create new boundaries without limitation and exploit the potential of this development to free himself from contradiction in his identity and comeback as a great hacker.
\end{abstract}

Keywords-hyperreality; identity; hyperreal identity; technology

\section{INTRODUCTION}

Nowadays many movies talking about human live in different world which full of equipment that already work with high quality of technology are being played in the movie theatre and TV. They are "Matrix", "Blade Runner", "The Truman Show", "Vanilla Sky", "The Minority Report" and "Inception" [12]. These movies display the idea of hyper reality in a clear cut way. Quite similar to movies, any discussion about hyperreal identity through novel is also still possible. The discusison on Lauren Miller's Free to fall, Margaret Atwood's Oryx and Crake, Don Delilo's White Noise already could give a different color to litearry discussion on hyperreal identity [11]; [2]; [5]. However, another perspective talking this idea is still welcoming including from the novel Neuromancer by William Gibson [9].
Topic on hyperreal identity is getting popular because the reader starting could see interets point. When the world has given a choice to the character to form the self of him or her, people tend Each individual will consider about the real of he or she since he or she was born and starting that time he or she will consider thet there is identity that follows him or her. This identity also grows through the process of seeing, experiencing moments and also copying the habit of family, friends, culture and environment around him or her that shape who and what really he or she is. Identity is a self portrait that is formed from many elements; vocational or career identity; political identity; religious identity; relationship identity; achievement; intellectual identity; sexual identity; cultural identity; interest; personality characteristic; physical identity [4]. In other words, identity deals with human motivation and goal pursuit which this situations make them bravely take risk actions to reach personal achievement in adolescence towards their goals and as an important step towards productive and useful adults for society. Some individuals also face obstacles which may prevent the development of their strong identity to be productive and useful adults for society that make them start to looking for chances to prove their real quality to society and also fulfil his own satisfaction of himself to reach their dreams.

Identity content appears in a wide range of literary forms, from poetry to short stories, plays and also novels. According to Victoria Grace who state that identity is a concept that is predicated on a "series of dichotomous separation", us and them, male and female, white and black, here and there, my nation and yours, and so on. These binaries are "premised on the illusory construction of an essence" [13]. However, the most explicit reference to the human mind is to be found in novels which deal with individuals' inner experiences, thoughts, feelings, emotions, depressions and introspections of their own identity. The instability of identity can be explained from the point of view of hyperreality. According to French sociologist, Jean Baudrillard [7], who believes that hyperreality goes further than confusing or blending the 'real' with the symbol which represents it, it involves creating a symbol or set of signifiers which represent something that does not actually exist [7]. In other words, hyperreality is seen 
as a condition in which what is real and what is fiction are seamlessly blended together so that there is no clear distinction between where one ends and the other begins. Constructing from three elements (simulation, simulacrum, hypereal) in the process of questioning the identity, hyperreality is created by offering conflicting sensory information that contrasts with a strong sense of the main character's own identity. This is what the novel of William Gibson, Neuromancer seems to be revealed.

Neuromancer novel talks about the construction of world where technology becomes the part of people lives. Humans and technology have an intricate connection that in many ways trumps the digital relevancy and technological dependency of today. Gibson develop a cast of character, Case, who is experience major changes in his own identity throughout the novel. Gibson ultimately shows that in a technologically dependent society, a person's identity is in a state of constant flux which it is no longer defined by its superficial, cultural, or social characteristics, rather one's identity is an evolving construct that is wholly dependent on the technology that it embraces. However, the technological development has caused the emergence of hyperreality. Hyperreality blurs the boundaries between the real and the fake. In the novel, hyperreality appears when technology has succeeded to create the simulated virtual identity in novel's characters.

A quote by Dorothy West said, "Identity is not inherent. It is shaped by circumstance and sensitivity and resistance to self-pity". Moreover, this novel has attracted critical attention from the time it was first published in the forms of review, essay, documentaries and adaptations. These reasons are considered for this study to choose Neuromancer novel to be analyzed. Directing a study to Neuromancer with the topic of hyperreal, this study examines: 1) Hyperreal identity being depicted in William Gibson's Neuromancer, and 2) The development process of Case to live with hyperreal identity.

\section{HYPERREALITY THEORY}

Hyperreality theory formulated by French sociologist, Jean Baudrillard, and clustered in postmodernism school. According to Jean Baudrillard, who believes that hyperreality goes further than confusing or blending the 'real' with the symbol which represents it, it involves creating a symbol or set of signifiers which represent something that does not actually exist [7]. Baudrillard defined "hyperreality" as "the generation by models of a real without origin or reality; "hyperreality is a representation, a sign, without an original referent. The prefix 'hyper' signifies more real than real whereby the real is produced as per model. Baudrillard in particular suggests that the world we live in has been replaced by a copy world, where we seek simulated stimuli and nothing more.

However, Hyperreality consists of three parts: simulation, simulacrum and the last is when the condition finally called as hyperreality. Simulation and simulacra is most known for its discussion of symbols, signs, and how they relate to contemporaneity (simultaneous existences). The three parts is an inseparable chain in hyperreality theory. The next few paragraphs will explain each part in the chain of hyperreality theory. The explanation will begin with simulation, continued with simulacrum and then hyperreality.

The first phase in the process in hyperreality theory is simulation development, a faithful image/copy, it may even be correct, that a sign is the "reflection of a profound reality". This is a good appearance, in what Baudrillard called "the sacramental order". However, It is the process of creating models of reality, something that never existed before and do not refer to any type of reality without any reference or origin from reality [10]. This is the basic phase which distinguish the real from its representation. This process involves creating an object that has never been made before, but it does not refer to any other objects that exist in the real world. However, fiction, hallucination and fantasy take a part in this process and materialized into something that can be seen and felt. Since the process of simulation does not refer to any type of reality, the object of simulation does not serve as a representation of reality but it is not a duplicate. Every process of simulation creates an object that has no similarity and relation with other objects in reality. Although through simulation process the object does not adopt any kind of reality, its appearance is similar to what people see in reality. According to Baudrillard claims that our current society has replaced all reality and meaning with symbols and signs, and that human experience is a simulation of reality. Simulation is the dominant schema in the current code governed phase [7]. So, simulation eliminates not only the difference between reality and sign but also original and fake, right and wrong, the real and the imaginary [10]. To make it easy to understand, Baudrillard [7] used Disneyland, a theme park built by Walt Disney, as an example for his theory. Disneyland is built as the representation of America where people can many kinds of rides and attractions that actually it describes America in the past, present and future. At this moment, Disneyland only seen as a theme park. Then the difference between Disneyland and America is firm.

The second phase, Simulation produces simulacrum, image masks and denatures a profound reality. Simulacrum is a model construction of an object that do not refer to any reality besides the object itself [10]. Image starts to develop as a corruption of reality. It is no longer seen as a representation but a simulation. Here simulation is from a radical negation of the sign [7].

As the example, Inside the Disneyland people can find so many castles which are fake castles that appear to present the form of real castle because people always think that those castles are how the castles should ideally look like. People do not realize that actually thee fake castle masks the real castle. Simulation's aim is to make people realize that the reality created by simulation is real.

The third phase, image masks the absence of a profound reality. Despite lacking of presence, image as simulation tries to present the absence of reality [7]. In the third phase, image as the sign in the form of simulation appears to strengthen the simulation as the real reality. The sign starts to lose connection with the real signified. For example, all the created 
environments inside the Disneyland, the horses, the castles and the streets, have been built to look realistic. The technology that used in Disneyland has already succeeded to attract people and make them think that all of these copies are original.

The fourth phase, image has no relation to any whatsoever; it is its own pure simulacrum. Moreover, these simulacra are not merely mediations of reality, nor even deceptive mediations of reality; they are not based in a reality nor do they hide a reality, they simply hide that nothing like reality is relevant to our current understanding of our lives. Image no longer represents any meaningful reality and has completely lost connection with the real signified. Instead, the sign creates its own reality. Simulacrum object which is the result of simulation process is a copy of a copy which has been so dissipated in its relation to the original that it can no longer be said as a copy of a copy, means that it is an icon which already degrades into the least resemblance or likeness or even to the level when it has no similarity with the original object. It can be easy to understand that the simulacrum here is actually a copy of an object from the reality, but since it is made through the simulation process, it cannot be said as a copy anymore because it does not resemble its origin object, or in other words it becomes a new model, no longer a copy. So, Disneyland as the example, is no longer a representation of America but the simulated America. Unlike representation which strives to absorb simulation by interpreting it as a false representation, sign in form of simulation warps representation as a simulacrum [7]. The simulacrum that Baudrillard refers to are the significations and symbolism of culture and media that construct perceived reality, the acquired understanding by which our lives and shared existence is and are rendered legible; Baudrillard believed that society has become so saturated with these simulacra and our lives so saturated with the constructs of society that all meaning was being rendered meaningless by being infinitely mutable. Baudrillard called this phenomenon the "precession of simulacra". Moreover, simulacrum is a simulation of endless simulations that blurs any relation to reality because the boundary between real and imagination is not clear anymore, then creates a condition of hyperreality. Baudrillard [7] describes hyperreality as "the generation by models of a real without origin of reality" [7]. It means that hyperreality is representation without original referent. It is just a distraction from a real world which is in itself unreal.

According to Jean Baudriallard, who believes hyperreality is a condition where something unreal is believed as reality and can be more real than the real, it has caused the discontinuity between the real and the fake. It also interrupts people's way of thinking in which they cannot differentiate between the real and the fake [7]. Baudriallard [7] also emphasized that in hyperreality, models of reality dissolve in a hyperspace without an atmosphere which refers to the experience in changes of appearance or surface in a space, blending and dissolving reality with fantasy, fiction, hallucination, nostalgia, disguising the difference between each other. Back to Disneyland as the example, appears as the theme park is slowly interpreted as the simulation of America and once again changes to be America. At first, Disneyland is built as a distraction of people's hectic lives then it develops into the ideal world that people crave for which full of happiness, a play of illusion and seen as the imaginary world.

In hyperreality, there is an object which the models of reality can explore more freely than reality including their role, its appearance is more appealing than reality. So, the object that has motifs which are motivate its dream to reach its goal to look better than the real and create something new at the same time. People feel more touched when undergoing a simulation or seeing a simulation than when they are seeing or feeling real emotions. The fulfillment of emotions or the search for happiness is found through simulation [7]. So, it means that actually people prefer the simulation instead because it gives them happiness that they do not get in real. However, the clearer steps about the phases of image and the examples can be seen in the following diagram below:

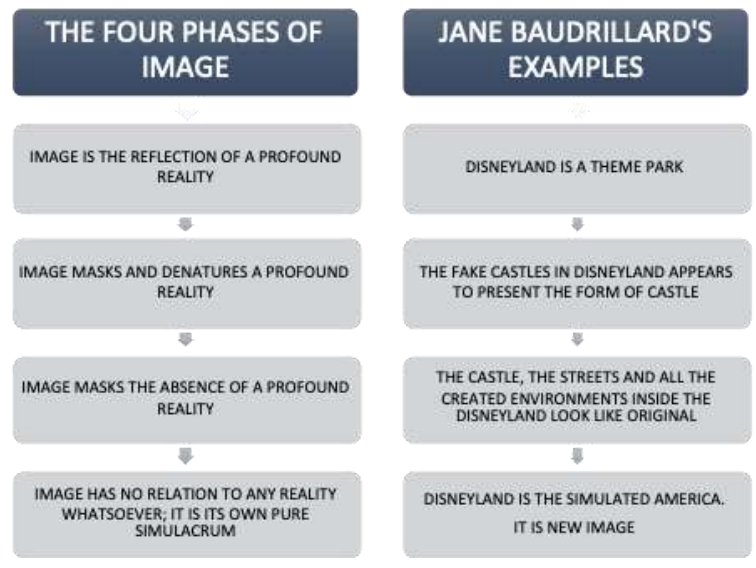

Picture 1 The Diagram of Jean Baudrillard's Hyperreality Theory

\section{RESULTS AND DISCUSSION}

\section{A. Hyperreal Identity of the Main Character}

The analysis about hyperrwal identity in Neuromancer has ever being done by Mohd Abas Parrey which title of his paper is Hegemonic Structure of Hypperreality andModern Technology in William Gibson's Novel Neuromancer [9]. Paper by Parrey and this study has the same point to be clarify, its about the hyperreal identity. However, there is big difference among them. Parrey explain hyperreal under the head The technologyng of self-estimation and loss of freedom, world of crime and violence, and love and betrayal in modern society. Furthermore, in this study the hyperreal identity is being described by giving the process how the identity is constructed, starting from the first stage to fourth stage. Another difference focus also being explain by Benjamin Fair, whose discussion goes to postmodern idnetity that exist in William Gibson's Neuromancer [1]. The other studies on Neuromancer talked about the cybernetics and its art, and trancendence through Detourrnement [6]; [3]. 
Having deeper analysis on hyperreal identity of Case in this novel, the discussion will be started by talking about the very far future interaction between humankind and machine which is no longer solely driven by human input, but also by the will or programming of the technology they are working with. In this context, technology is the object of the hyperreality in Neuromancer.

"The sky above the port was the color of television, tuned to a dead channel." [14]

From the first line in part 1 Chiba City Blues, it can be seen how importance of machinery in this world. It is very commonly used metaphorically to describe something that is free technology such as the sky. As the opening of the novel, this sentence prepares everybody well for a world where there remains very little difference between the natural and the artificial or machine made by technology. Whereas in the past the relationship between humankind and machine was instrumental in nature in the sense that humankind exploited technology then this has changed with the coming of new technology.

Gibson through this novel looks technology that affect the question of identity "who am I?" , the relation of human and the machine, creating copies of people's minds of changing one's mind or identity and joining together or merging two entities. So, identity here in Neuromancer is identity in cyberspace. In the cyberspace, one can design, define and redefine identity offers a challenge to the original definition of the self and identity once in cyberspace. While in the novel itself, human consciousness become bodiless and flies in cyberspace, using data that is available while at times also existing in bodily form in the landscape of everyday. When jacked into cyberspace, the individual is physically in front of the computer screen while mentally he is in the cyberspace. Neuromancer explained well cyborg which can be represented as a human who conceived coded devices in the body which will then lead to posthuman or it can be seen as a mean of survival to have machines implanted in the body system just like main protagonist character. However, there are two distinct types of cyborgs in Gibson's Neuromacer that first is a posthuman body and second is a machine dominated beast.

At the beginning Case introduced as a protagonist character that becomes the focus of the novel as an 'excowboy.

Case was twenty-four. At twenty-two, he'd been a cowboy a rustler, one of the best in the Sprawl. He'd been trained by the best, by McCoy Pauley and Bobby Quine, legends in the biz. He'd operated on an almost permanent adrenaline high, a byproduct of youth and proficiency, jacked into a custom cyberspace deck that projected his disembodied consciousness into the con sensual hallucination that was the matrix [14]

The quotation above portrayed the introduction of Henry Dorsett Case's identity in the past as the best talented computer hacker. This explained well about Case image background and his experiences.
The main character, Case looks at technology as something that redemptive which offers him an option to reformulate or modify his feedback systems so that their human condition is refined in an attempt to attain what they suppose is an ideal selfhood

"A year here and he still dreamed of cyberspace, hope fading nightly. All the speed he took, all the turns he'd taken and the corners he'd cut in Night City, and still he'd see the matrix in his sleep....." [14]

From that sentence it states that Case is really addicted to technology. In the introduction to such a world, Case, who spent his entire life mentally entangled with computer system then without this capability, he feels incomplete and unfulfilled. Meanwhile in the beginning in the story clearly explain that Case associates his identity wholly with his job so he sees himself only as a useless thug for-hire without his ability to jack into cyberspace. Then Armitage appears to offer Case a job to repair his damage system and this create a hope for him to get back his abilities.

There are two distinct types of cyborgs in Neuromancer, first is a posthuman body and second is machine dominated beast. The diversification between posthuman body cyborg and machine beast cyborg is the flesh or meat on the body in the cyborg biomedical. Machine dominated beast in Neuromancer can be Neuromancer and Wintermute who are called the Artficial Intelligence. This distinction suggests that true identity lies outside of the physical body. Wintermute exists as a mental identity with no defined physical form, borrowing figures from Case's memory to be able communicate.

"Winterminute was a simple cube of white light, that very simplicity suggesting extreme complexity." [14]

From teh quotation above, it shows that Winterminute is represented as a cube of white light, but later it transforms into the people from Case's past to communicate with Case or someone from Armitage's past to communicate with Armitage. As data, Winterminute can transform depending on who's accessing it. However when this novel talking about how technology can including the transformation so it can also conneted to the memory of the characters.

"And now he remembered her that way, her face bathed in restless laser light, features, reduced to a code: ..." [14]

"He" in that sentence referred to Case and "her" referred to Linda Lee, from that sentence we know that technology affects the memories of the characters throughout the novel. Case describes his first meeting with Linda lee envisions her in term of computer code. When you consider how nerdy Case can be, however, it's actually kind of sweet part of him. In other way, the post human condition allows the possibility of extending the human senses through the use of technology. In the Neuromancer fantasizes world, the ability of the human and machine interface to heighten the powers of man in such a way that one can not only extend one's senses but also extend it beyond oneself to enter into the mind of another human, 
another character. However, the characters in this novel succeed in completely injecting themselves into cyberspace. For example, when Case employs computer mediated environments to enter into Molly's senses and succeeds in sensing whatever she senses, seeing what she sees, and feeling what she feels.

"How you doing, Case?" He heard the words and felt her form them. She slid a hand into her jacket, a fingertip circling a nipple under warm silk. The sensation made him catch his breath. She laughed. But the link was one-way. He had no way to reply [14].

That conversations that the idea of consciousness as fluid, not tied down to a singular body, is further explored in the novel when character can jack into another person's consciousness a rider and experience the same thing of sensations as they do yet not control the physical embodiment of other person as when Case enters Molly's mind while she was in the black market. He watches as she prowls down an alley. He feels her fear, finds the experience frightening, frustrating and disorienting at first, but he eventually gets used to it.

Pretending the self as something which is flexible between two world, hyperreal identity that is defined by Lucas D. Introna is different perspective. Introna states that hyperreal idnetity is just like plastic [8]. Someone can change to be anyone else as easy as he/she changes clothes. Furthermore Introna believes that no matter where someone is located, she/he needs others to give meaning to its life.

\section{B. The Development of hyperreal identity of the main} character, Case

Case's hyperreal identity has been affected during his finding identity process. It means his hyperreal identity development following his identity process. The more he tries find out about himself, his hyperreal identity becomes more real. How the character finanly found his/her hyperreal identity also happened to main character, Jimmy in Atwood's Oryx and Crake, that he has already enjoy the unreal world which is represented by games in CDs, and on the web [2]. The characters had eliminated the reality and build their hyperreal world. It sows that the hyperreal world has made the people inside feel comfortable easier than the character in Neuromancer.

In Neuromancer, the character experienced four phases of identity development. The first phase in the process in hyperreality theory is simulation development;

"Case was twenty-four. At twenty-two, he'd been a cowboy a rustler, one of the best in the Sprawl..."

"A year here and he still dreamed of cyberspace, hope fading nightly. All the speed he took, all the turns he'd taken and the corners he'd cut in Night City, and still he'd see the matrix in his sleep...." [14].

Both of this quotations above is clearly explained the situation when he missed his real identity as the best Cowboy in the Sprawl and introduced Case as a depressed has been hacker that, Due to nervous system damage from a previous employer which is he no longer able to enter and jack into the cyberspace.

In his hacking glory days, Case began to develop a hatred of his physical self, and once crippled felt like a prisoner in his own body.

Strapped to a bed in a Memphis hotel, his talent burning out micron by micron, he hallucinated for thirty hours. The damage was minute, subtle, and utterly effective. For Case, who'd lived for the bodiless exultation of cyberspace, it was the Fall. In the bars he'd frequented as a cowboy hotshot, the elite stance involved a certain relaxed contempt for the flesh. The body was the meat. Case fell into the prison of his own flesh [14].

From the quotation above, it portrays the important aspect of the novel as well as cyberspace in particular. In this world, being online and jacked into the matrix represents freedom. Then living in one's own biological body is like going to prison. At this point in Case's life, his identity was defined by his incapacity. This study found that this incapacity was a result of seemingly irreversible ttechnology that is loss his capability. While this is especially true for cyber cowboys and their relationship to cyberspace, it is also accurate for other characters in different ways.

The second phase when the simulation produces simulacrum when the image starts to develop as a corruption of reality;

"The Sprawl was a long strange way home over the Pacific now, and he was no console man, no cyberspace man, no cyberspace cowboy. Just another hustler, trying to make it through." [14]

The quotation above tells the condition of Case when he lost his ability. Case's inability to be a console cowboy seems to change himself, how he value himself. He thought of himself as unstoppable as a console cowboy until they put a kind of poison (a wartime Russian mycotoxin) as a punishment for him. Now he got new identity as a hustler and he holds no value in what he is anymore. The third phase,image masks the absence of a profound reality, where the sign starts to lose connection with the real signified. As Case returns to the Console, he regains the image of himself that he once had in his earlier, so Case's identity shifts at this moment, as he returns to the Console and his technology.

The fourth phase, image has no relation to any whatsover means pure simulacrum which no longer represents any meaningful reality and has completely lost connection with the real signified. One thing that actually represents well in this novel is transformation of Case that he wants change throughout the novel. In his plea to 3Jane for the password, he says,

"I got no idea at all what'll happen if Wintermute wins, but it'll change something!" [14]

From Case, he make peace with his past (with his Linda). He decides to move forward even if that means moving into 
the unknown. All this new situation is better than a coffin in a capsule hotel. The changed identity, influenced by surrounding that is full with technology which are unlimited to Case. Sure, he is still a rough and subtle guy who will walk the straight and narrow anytime soon, but honestly he is a bit more shaded and nuanced. Most importantly, finally he got back his hack ability, it means his life after all of his journey.

\section{CONCLUSION}

It is clear from an examination of this novel that the writer is ambivalent about the influence of technology can affect the identity and create hyperreal identity. This novel dismal dystopian cities where people live under the constant control of multinational corporations which this this novel actually has characters who move beyond the boundaries set by their societies, some even changing completely in the process of becoming "posthumans". The technology here seems as drug or malignant, depending on the way it is used by powerful multinational corporations or individual cyberpunk cowboys or hackers.

The finding identity process develop Case's hyperreal identity can be seen from the part when he try to get back his ability as a cowboy and enter the cyberspace. All experience and his story brings him into the journey of his identity process that help him find his hyperreal identity. Case has been born into a world of technology and he is continually comparing his experience by creating comparisons with cyberspace. As a result reality and cyberspace often tend to merge in this novel. Even though these technological and medical advances allow Case to access the matrix, he has removed their personal choice and he becomes trapped by the possibilities that the new technology offers. For Case, the body eventually becomes a place of security and belonging self acceptance in contrast to the insecurity and alienation of cyberspace. Case finds his own identity when he crashes
Neuromancer's construct, but it does grant Case's peak of his ability through the brain's pharmacy. The important thing is his body becomes his own space as much as any space can be.

\section{REFERENCES}

[1] B. Fair, "Stepping Razor in Orbit: Postmodern Identity and Political Alternatives in William Gibson's Neuromancer," Crit. - Stud. Contemp. Fict., vol. 46, no. 2, pp. 92-103, 2005.

[2] B. Pourgharib, "Baudrillardian Concepts of Hyperreality and Simulacra in Margaret Atwood' s Oryx and Crake Afsaneh Pourebrahim," Khazar J. Humanit. Soc. Sci., vol. 21, no. 4, pp. 36-54, 2018.

[3] G. Grant, "Transcendence Through Detournement in William Gibson's Neuromancer," Sci. Fict. Stud., vol. 17.1, pp. 41-49, 1990.

[4] G. R. Medinnus, Readings in The Psychology of Parent-Child Relations. Jersey: Wiley, 1967

[5] I. R. Khaleel, "Traumatic Hyperreality in Don Delillo 's White Noise," Coll. Educ. Humanit., vol. 8, 2016.

[6] I. Csicsery-Ronay Jr, "The Sentimental Futurist: Cybernetics and Art in William Gibson's Neuromancer," Crit. - Stud. Contemp. Fict., vol. 33.3, pp. 221-241. DOI: 10.1080/00111619.1992.9937885, 1992.

[7] J. Baudrillard, Clone Story' in Simulacra and Simulation. Ann Arbor: The University of Michigan Press, 1994

[8] L. Introna, "On Cyberspace and Being: Identity, Self, and Hyperreality," Philos. Contemp. World, vol. 4, no. 1, pp. 16-25, 1997.

[9] M. A. Parrey, "Hegemonic Structure of Hyperreality and Modern Technology in William Gibson' S Novel Neuromancer," International Journal of Development Research, vol. 07, pp. 14589-14592, 2017.

[10] N. K. Ratna, Teori, Metode, Dan Teknik Penelitian Sastra (Dari Strukturalisme Hingga Postrukturalisme, Perspektif Wacana Naratif). Yogyakarta: Pustaka Pelajar, 2004

[11] R. M. Wanodya, H. Pujiati, I. Astutiningsih, and U. Jember, "The Hyperrealities in Cyberpunk Novel Free to Fall by (Hiperrealitas Dalam Novel Cyberpunk Free to Fall Karya Lauren Miller)," vol. 3, no. 2, pp. 39-51, 2015.

[12] S. Bharathi and T. A. I, "Hyperreality as a Theme and Technique in the Film Truman Show," Glob. Media J., vol. 16, no. 30:90, pp. 1-5, 2018.

[13] Victoria Grace, Baudrillard's Challenge: A Feminist Reading. Routledge, Ed. London, 2000.

[14] W. Gibson, Neuromancer, 1984. 